\title{
A STUDY OF THE VALUE OF DIMENHYDRINATE AND PROMETHAZINE HYDROGHLORIDE IN THE CONTROL OF POST-ANAESTHETIC VOMITING*
}

\author{
R. A. GopDON, M.D., F R.C.P.(c), F.F.A.R.C.S., \\ S. L. 'VANDEWATER;' M.D., F.R.C.P.(C), \\ G. E. Sleath, B.A., M I., and Doreen Caplin, M.D.**
}

THE occurrence of vomiting in the post-operative period has been one of the most constantly observed complications of the anaesthetce era. This complication is usually simply annoying and unpleasant, although occasionally the patient may in this manner lose sufficient fluid and electrolyte to prejudice his recovery. Many of the causes remain obscure and it has been for generations the hope of anaesthetssts, surgeons and patients alike that this complication of the postoperative period might be eliminated, or abated. Each new anaesthetic agent and technique has been carefully evaluated for its influence in this respect. Despite all such research and evaluation, vomiting has remained a common and unpleasant feature of the post-operative period in a significant proportion of surgical patients

Lee ( 1 ) states that vomiting may be influenced by one or more of the following factors: (a) anaesthetic agent and technique (b) type of patient (c) condition of the stomach (d) morphine (e) type of operation and ( $f$ ) sex. Davis (2) found that nitrous oxide, oxygen and ether combination produced the highest incidence of post-operatuve vomitnng, but the preliminary addition of $5 \%$ Pentothal reduced the incidence by almost $20 \%$. The addition of cyclopropane to the anaesthetic sequence appeared to have little effect on the vomiting rate. In minor gynaecological procedures, all including dilatation of the cervix, he reports $64 \%$ vomited. Concernıng sex incidence, the ratio with gas/oxygen/ether was 68.6 females to 45.5 males. Smith (3) concluded that the duration of anaesthesia was a definite factor in the amount of constitutional upset, and suggested that it may be due to production of slight degrees of anoxia by surgical shock; but he found the incidence of vomiting in children did not appear to be significantly altered by duration of anaesthesia.

The mechanism of vomiting involves the coordinated actions of the muscles of the stomach, oesophagus, and abdominal wall. The act may also be associated with ant-peristaltic movements in the intestne (4). According to Barclay (5) just prior to the commencement of vomitng movements a sudden reduction of gastric tone occurs, comciding with the sensation of nausea. The muscular mechanisms are governed by a centre in the medulla, situated in the neighborhood of the dorsal nucleus of the vagus, close to but quite distinct from the respiratory centre. The centre is stimulated by mechanical or chemical irritants

\footnotetext{
'Presented at the Annual Meetıng, Canadian Anaesthetısts' Society, at Vancouver, British Columbia, June 14, 1954

" From the Department of Anaesthesia, Faculty of Medicme, University of Toronto.
} 
acting upon vagal or sympathetic afferent terminals, by certain substances such as apomorphine, emetine and picrotoxin which directly raise the excitability of the tissue, and by elevation of intracranial pressure or anaemia which raise excitability through interference with blood supply. It seems logical to assume that vomiting, can be prevented by avoiding stimulating substances, or by depression of txe vomiting centre.

Prophylactic measures to reduce post-operative nausea and vomiting are outlined by Hewer (6) as the following: (a) suitable preparation-no solid contents in the stomach, (b) glucose 24 hours pre-operatively, and in an enema postoperatively, (c) post-operative insulin (usually 10 units) in addition to the glucose if a considerable amount of ether has been used, (d) a basal narcotic or induction with intravenous barbiturate, (e) the use of minimal quantities of toxic drugs such as ether and chloroform, (f) hyperventilation for a short time with carbon-dioxide after long operations using much ether, $(\mathrm{g})$ elimination to a large extent of the pyschic factor by suitable suggestion during the induction, and $(h)$ earlier post-operative feeding, but avoiding milk, orange juice, or fats.

The use of Insulin was first reported by Minnit (7), who showed that postanaesthetic toxic symptoms and acetonuria were associated with a high blood sugar, and that control of the latter by insulin relieved the nausea and vomiting. Smith (8) corroborated Minnit's work, but widespread use of insulin postoperatively has not been reported.

In 1947, Bergmann (9) reported a series of 12 cases to whom $100 \mathrm{mgm}$. of pyridoxine was given pre-operatively and one hour post-operatively, with no vomiting and only slight nausea. More recent work by Kernis and Stodsky (10) and by Hill (11) has failed to confirm his findings.

In 1947 Gay and Carliner (12) administered dimenhydrinate to a pregnant woman who complained of urticaria, and who incidentally had suffered all her life from car sickness. Unexpectedly the car sickness was relieved as well as the urticaria. In 1948 they carried out extensive studies on the effect of dimenhydrinate on seasickness, and reported favourably on it. Carliner et al. (13) extended its use to nausea and vomiting of pregnancy, Beeler et al. (14) to radiation sickness, and Campbell (15) to the treatment of vestibular reactions following the labyrinthine fenestration operation.

Paterson (16) in 1949 used dimenhydrinate for post-operative vomiting. $\mathrm{He}$ dissolved $100 \mathrm{mgm}$. of the drug in 30 c.c. of water, and administered it per rectum with the advent of post-operative nausea and vomiting. It was found that rarely more than one administration was necessary, and relief was obtained in 20 or 30 minutes. Rudolph (17) gave $100 \mathrm{mgm}$. orally one half hour pre-operatively. In cases with post-operative nausea and vomiting he used $100 \mathrm{mgm}$. suspended in 20 c.c. of isotonic sodium chloride, and given rectally. He reports excellent results on 22 cases. Wolfe (20) compared the incidence of nausea and vomiting in a series of 143 patients given dimenhydrina e before and after operation with the incidence in a control series of 139 paients, and concluded that dimenhydrinate reduced post-operative nausea and vomiting, but that the reduction was not great enough to warrant its routine use on a general surgical service. 
The use of promethazine hydrochloride as an anti-nauseant and anti-emetic has been recorded in the literature by a number of authors since 1948 (21) $(22),(23),(24)$. These reports refer to its use in the control of motion sickness, the nausea and vomiting of pregnancy, and drug reactions.

The present study was undertaken to determine the efficacy of dimenhydrinate and of promethazine hydrochloride (dibenzoparathiazine) in the control of post-operative nausea and vomiting. ( $\mathrm{n}$ each case the doses used were those recommended for the purpose by the manufacturers of the drugs, at the time when the study was undertaken.) Promethazine $\mathrm{HCl}$ is marketed by Poulenc Limited under the trade-name "Phenergan", and Dimenhydrinate by F. W. Horner \& Co. as "Gravol" and by the G. D. Searle Co. as "Dramamine".

\section{Methods}

In the mitial phases of this study, dimenhydrinate was administered one hour pre-operatively in the form of a rectal suppository containing $100 \mathrm{mgm}$. of "Gravol" in a surtable base. These patients were compared with a similar series who received no suppository. In the second phase dimenhydrinate was administered by the intramuscular route in doses of $50 \mathrm{mgm}$. pre-operatively, followed by $25 \mathrm{mgm}$. every four hours post-operatively for four doses. Promethazine $\mathrm{HCl}$ was used by intramuscular injection of $50 \mathrm{mgm}$. pre-operatively or at operation, followed by $50 \mathrm{mgm}$. intra-muscularly q.4.h. for two doses postoperatively. Both injection series were compared with a similar number of patients who recerved a similas injection of normal saline from an ampoule identical with the Phenergan ampoule and labelled "Phenergan Control", neither the nurses or the patients being aware that the control ampoules had been substituted for the Phenergan. In addition, 100 obstetrical patients were given a single intra-muscular injection of Promethazine $\mathrm{HCl} 50 \mathrm{mgm}$. on admission to the delivery room, and the incidence of vomitng and infant depression in these patients was compared with that in 100 patients who received a similar injection of saline from ampoules of "Phenergan Control", and with a like number who recerved no injection.

Some selection of cases was used. To eliminate the factor of gastric contents, no emergency procedures are mcluded in the series except in the case of the obstetrical patents. No spinal anaesthetics are included in the series, and patents who had duodenal tubes for post-operative draurage were eliminated. In the series of patients who recelved dimenhydrmate in a rectal suppository patients having rectal or vagnal operations were excluded. In this series, too, twelve patients who did not receive pre-operative enemas are excluded from the analysis because of the possibility of impaired absorption from a full rectum, while 6 patients who received suppositories and 6 of the control series are excluded because they did not receive morphine in the pre-oserative preparation.

For the purposes of this report vomitng only is recorced, since this is an objective phenomenon which cen be accurately recorded by an observer. In the patients who had rectal suppositories the patients were questioned about nausea and vomiting, and nursing, notes were checked, although these were found generally to be incomplete. "he control series for this portion of the investigation 
was checked in the same way. As pointed out by Hill (11), this method of follow-up is not ideal, for discomfort experienced during the first 6 hours or so after recovering from anaesthesia is often forgotten by patients, and is not forthcoming on routine questioning. In the injection series s jecial records of vomiting were maintamed by the nursing staff, and any recorc which was found to be incomplete was rejected.

In the dimenhydrinate suppository series all patients had morphia and atrophine as pre-operative medication. In the subsequent series no selection. of cases was made on this basis, although the usual pre-operative sedative was morphia gr. $1 / 6$ or gr. ${ }^{\prime \prime}$ with atrophine gr. $1 / 150$, given 45 minutes pre-o seratively.

No differentiation is made between general anaesthetic agents in tuis report. The patients were anaesthetized with ether, cyclopropane, nitrous oxide combined with pentothal or trichlorethylene, with the -requent addition of various relaxant drugs.

\section{Results}

\section{Dimenhydrinate}

\section{A. Suppositories}

The effect of the routine use of dimenhydrinate suppositories as a preoperative measure for the control of vomiting under the conditions outlined above is shewn in Table I.

TABLE I

\begin{tabular}{|c|c|c|c|c|c|c|}
\hline & \multicolumn{2}{|c|}{ No vomiting } & \multicolumn{2}{|c|}{ Vomited } & \multicolumn{2}{|c|}{ Total } \\
\hline & Number & $\%$ & Number & $\%$ & Number & $\%$ \\
\hline $\begin{array}{l}\text { "Graval" } \\
\text { Suppository } \\
\text { (100 mgm) }\end{array}$ & 47 & $567 \%$ & 36 & $433 \%$ & 83 & $100 \%$ \\
\hline Control & 39 & $415 \%$ & 55 & $585 \%$ & 94 & $100 \%$ \\
\hline Difference & & $152 \%$ & & & & \\
\hline Standard E & fference $=$ & $44 \%$ & & $S E=1$ & $\%$ & \\
\hline
\end{tabular}

\section{B. Injection}

The effect of dimenhydrinate given parenterally on post-operative vomiting is shewn in Table II. Fifty milligrams of the drug was injected either intramuscularly ( 70 cases) or intravenously ( 24 cases) at the time of operation, and $50 \mathrm{mgm}$. intramuscularly every four hours for four doses post-operatively.

\section{Promethazine $\mathrm{HCl}$}

The effect of post-operative vomiting of promethazine $\mathrm{HCl}$ given routinely to general surgical patients is shewn in Table III. Fifty milligrams was given intramuscularly during operation, and twenty-five milligrams every four hours for four doses post-operatively. 
TABLE II

\begin{tabular}{|c|c|c|c|c|c|c|}
\hline & \multicolumn{2}{|c|}{ No vomiting } & \multicolumn{2}{|c|}{ Vomited } & \multicolumn{2}{|c|}{ Total } \\
\hline & Number & $\%$ & Number & $\%$ & Number & $\%$ \\
\hline $\begin{array}{l}\text { Dimenhydrinate } \\
50 \text { mgm I Musc or } \\
\text { I V. during operation } \\
50 \text { mgm q } 4 \mathrm{~h} \times 4 \\
\text { I Musc after operation }\end{array}$ & 69 & $734 \%$ & 25 & $266 \%$ & 94 & $100 \%$ \\
\hline $\begin{array}{l}\text { Control (Injection of } \\
\text { saline from ampoules }\end{array}$ & 35 & $584 \%$ & 25 & $416 \%$ & 60 & $100 \%$ \\
\hline Difference & & $15 \%$ & & $15 \%$ & & \\
\hline Standard Error of diff & rence $=$ & & $2 \times$ S.E & $1561 \%$ & & \\
\hline
\end{tabular}

TABLE III

\begin{tabular}{|c|c|c|c|c|c|c|}
\hline \multirow{2}{*}{$\begin{array}{l}\text { PromethazInE } \\
\text { General surgery }\end{array}$} & \multicolumn{2}{|c|}{ No romiting } & \multicolumn{2}{|c|}{ Vomitıng } & \multicolumn{2}{|c|}{ Total } \\
\hline & Cases & $\%$ & Cases & $\%$ & Cases & $\%$ \\
\hline $\begin{array}{l}\text { Promethazine } \mathrm{HCl} \\
-50 \mathrm{mgm} \text { at } \\
\text { operation } \\
-25 \text { mgm q } 4 \mathrm{~h} \times 4\end{array}$ & 58 & $893 \%$ & 7 & $1072 \%$ & 65 & $100 \%$ \\
\hline $\begin{array}{l}\text { "Control"- } \\
\text { Injection of } \\
\text { Physiological saline } \\
\text { from ampoules }\end{array}$ & 35 & $584 \%$ & 25 & $416 \%$ & 60 & $100 \%$ \\
\hline Difference & & $309 \%$ & & $309 \%$ & & \\
\hline
\end{tabular}

The effect on post-partum vomiting of a single dose of $50 \mathrm{mgm}$. of Promethazine $\mathrm{HCl}$ given to unselected obstetrical patients is shewn in Table IV. The effect of the drug on the response of the infant is also assessed.

\section{Discussion}

The difficulty of assuring accurate recording in a study such as this in a busy General Hospital has been mentioned above. We have attempted to overcome inaccuracy in this respect by rejectung all records in which there appeared to be some doubt of completeness or accuracy. While this has greatly reduced the total number of cases included in the analysis we feel that the gain in accuracy outweighs the statistical disadvantage of the shorter series. 
TABLE IV

\begin{tabular}{|c|c|c|c|c|c|c|c|c|c|c|c|c|}
\hline \multirow{3}{*}{$\begin{array}{c}\text { PrometHAZINE } \\
\text { Obstetrical } \\
\text { Patients }\end{array}$} & \multicolumn{6}{|c|}{ Mother } & \multicolumn{6}{|c|}{ Infant } \\
\hline & \multicolumn{2}{|c|}{ Vomited } & \multicolumn{2}{|c|}{ No vomiting } & \multicolumn{2}{|c|}{ Total } & \multicolumn{2}{|c|}{ Depression } & \multicolumn{2}{|c|}{$\mathrm{O}_{2}$} & \multicolumn{2}{|c|}{ Intubated } \\
\hline & Cases & $\%$ & Cases & $\%$ & Cases & $\%$ & Cases & $\%$ & Cases & $\%$ & Cases & $\%$ \\
\hline $\begin{array}{l}\text { Phenergan } \\
50 \text { mgm before } \\
\text { delivery } \\
100 \text { patients }\end{array}$ & 20 & $20 \%$ & 80 & $80 \%$ & 100 & $100 \%$ & 28 & $28 \%$ & 19 & $19 \%$ & 8 & $8 \%$ \\
\hline $\begin{array}{l}\text { "Phenergan } \\
\text { Control" } \\
\text { (Salne) } \\
100 \text { patients }\end{array}$ & 35 & $35 \%$ & 65 & $65 \%$ & 100 & $100 \%$ & 21 & $21 \%$ & 19 & $19 \%$ & 8 & $8 \%$ \\
\hline $\begin{array}{l}\text { No Injection } \\
\text { (100 patients) }\end{array}$ & 32 & $32 \%$ & 68 & $68 \%$ & 100 & $100 \%$ & 10 & $10 \%$ & 9 & $9 \%$ & 5 & $5 \%$ \\
\hline $\begin{array}{l}\text { Difference } \\
\text { between } \\
\text { Promethazıne } \\
\text { and Control }\end{array}$ & & $15 \%$ & & $15 \%$ & & & & $7 \%$ & & 0 & & 0 \\
\hline $\begin{array}{r}\text { Standard Erro } \\
\text { (Vorn }\end{array}$ & $\begin{array}{l}\text { of diffe } \\
\text { ting) }\end{array}$ & rence & $=62 \%$ & & & $\times \mathrm{SE}$ & $E=1$ & $24 \%$ & & & & \\
\hline
\end{tabular}

In judging the significance of dufferences in incidence of vomiting between the patients receiving the drugs and the controls we have followed the recommendation of Campbell (25) that a significant difference must be at least twice the standard error of the difference setween the percentage figures for the two series. It is seen, therefore, that the difference in vomiting following the routine use of a suppository containing $100 \mathrm{mgm}$. of Dimenhydrinate may be significant (Table I). The difference between those patients receiving Dimenhydrinate by injection in the doses used and those receiving injections of salune is on the border-line of significance (Table II), while the reduction of vomitung by Promethazine $\mathrm{HCl}$ in the doses used in this study is statistically significant (Table III, Table IV). It is evident, too, that Promethazine $\mathrm{HCl}$ produced no foetal depression when given in doses of $50 \mathrm{mgm}$. intramuscularly to obstetrical patients.

During the period of this study we made several interesting observations relating to the influence of psychic factors, including personal opinion, on the conduct of such a clinical research problem. It will be evident from a study of Table III that the vomiting rate was very low during the period of routine administration of promethazine hydrochloride by injection. We are of the opinion that it was probably less than the records show, since there appeared to be a tendency for the nurse to record vomiting when it occurred, and to forget to complete the record when there was no vomiting. When the control 
ampoules of saline were substituted for those of promethazine hydrochloride on the surgical service used for this study the vomiting rate increased suddenly', and for the first time the surgical and anaesthetic internes became aware that the patients were receiving routinely an injection of an "experimental" substance. This substance (saline control) was promptly credited with the production of vomitng, and we were firmly requested to cease its administration.

Durmy the study of the effect on the infant of Promethazine $\mathrm{HCl}$ given to the motzer, the obstetrical internes who were responsible for the decision as. to whether the mfant was or was not depressed had decided that the substance was producing foetal depression. It is evident from com sarison of the promethazine series and the saline control series in Table IV that this was not true, and the considerable drop in the infant depression rate when no injection was given probably represents the effect of this personal opinion.

\section{Conclusions}

From this study we have drawn the following conclusions.

1. The administration of Dimenhydrinate in a rectal suppository appears to reduce post-operative vomiting, but this form of dosage is cumbersome and is not considered suitable for routne use on a surgical service.

2. The routine parenteral admmistration of dimenhydrinate during operation and in the post-operative period under the conditions of this study appeared to reduce post-operative vomiting, but the statistical significance of the results obtained in this study is questronable, and we do not feel that the results justify the routine use of this substance as a prophylactic measure against post-operative vomiting on a surgical service.

3. The routme parenteral administration of Promethazine $\mathrm{HCl}$ under the conditions of this study produced a very significant reduction in the incidence of post-operative vomiting in general surgical patients, and in obstetrical patients, without evidence of foetal depression in the latter, and we believe that this substance may warrant routine use in such patients for the control of vomiting.

\section{SUMMARY}

The routine use of Dimenhydrinate ("Gravol", "Dramamine") and of Promethazıne $\mathrm{HCl}$ ("Phenergan") in the prevention of post-operative vomiting has been studied, using the drugs according to the dosage scale recommended by the manufacturers at the time this study was undertaken. The incidence of vomiting in these patients was compared with suitable control groups who did not receive the drug. Dimenhydrinate was given to surgical patients only, while Promethazine $\mathrm{HCl}$ was also tested in a singee dose series on obstetrical patients. In the obstetrical group it was demonstrated that in the dosage used Promethazine $\mathrm{HCl}$ did not depress the infant.

It is concluded that while Dimenhydrinate appears to suppress post-operative vomiting to some extent, the results in this study do not have sufficient statistical significance to warrant its use as a routine measure on a surgical service. Promethazıne $\mathrm{HCl}$ produced a very significant reduction in vomiting under the con- 
ditions of this study, and probably warrants further use as a prophylactic measure against post-operative vomiting.

\section{ACKNOWLEDGEMENTS}

We wish to express our appreciation to Professor D. E. Cannel, Professor of Obstetrics and Gynecology, Unversity of Toronto and Dr. F. G. Kergin, Chief of Surgical Service, Ward B, Toronto General Hospital, whose cooperation made this study possible. We wish also to acknowledge our indebtedness to Miss Lois Peacock, R.N., and the nursing staff of Ward B, Toronto General Hospital, and to Miss Jean Lawson, R.N., of the Burnside Division, Toronto General Hospital, for their generous assistance in administering the drugs and maintaining the records.

The Dimenhydrinate used in this study was generously supplied by F. W. Horner \& Co. in the form of "Gravol" suppositories and "Gravol" Injectable, and by G. D. Searle \& Co., as injectable "Dramàmine." The Promethazine $\mathrm{HCl}$ was supplied in the form of injectable "Phenergan" by Poulenc, Ltd., and we are also indebted to this house for providing us with control ampoules of saline labelled "Phenergan Control".

\section{RÉSUMÉ}

L'emploi régulier du Dimenhydrinate ("Gravol", “Dramamine") et du Prométhazine $\mathrm{HCl}$ ("Phenergan") pour la prévention du vomissement après l'opération a été étudié en employant les drogues selon l'échelle de dosages recommandée par les fabricants au moment où cette étude a été entreprise. I'incidence du vomissement de ces patients a été comparé à celui de groupes appropriés de contrôle qui n'ont pas reçu la drogue. Le Dimenhydrmate a été administré seulement à des cas chirurgicaux, tandis que le Prométhazine $\mathrm{HCl}$ a aussi été éprouvé en séries de dose unique, dans des cas obstétricaux. Dans le groupe obstétrical on a démontré que, suivant le dosage employé le Prométhazine $\mathrm{HCl}$ n’a pas amené une dépression chez l'enfant.

La conclusion est la suivante. Quoique le Dimenhydrinate semble supprimer à un certain degré le vomissement après l'opération, les résultats de cette étude n'ont pas une signification statistique suffisante pour justifier son emplo1 comme mesure régulière en chirurgie. Le Prométhazine $\mathrm{HCl}$ apporte une réduction de vomissement très significative, compte-tenu des conditions de cette étude et son emploi comme mesure prophylactique contre le vomissement après l'opération, se trouve justifié.

\section{REFERENCES}

1. LeE, J A A Synopsis of Anaesthesia; John Wright \& Sons, Ltd, 1950, pp 307

2. Davis, R. M Some Factors Affecting the Incidence of Post-Anaesthetic Vomiting, Brit. Med Journal 2. 578, (Oct. 23) 1941.

8 Sмптн, J M. Post-Operative Vomitng in Relation to Anaesthetic Tume, Bni. Med. Jour. 2. 2174, (AuE,. 18) 1945.

4. Best, C. E. anc Taylor, N B. The Physiological Basis of Medical Practice, The Williams \& Wilkms Co, 1950, pp. 574

5. Barclax, A E The Digestive Tract, Cambridge University Press, 1933 (Quoted by Best \& Taylor). 
6. Hewer, C L Recent Advanices in Anaesthesia \& Analgesia, J. A. Churchill Ltd., 1948.

7. Mannit, R. J A Successful Treatment for Toxic Symptoms Resulting from Ether Anaesthesia Based on Blochemical Investigation, Proc. Roy Soc. Med. (Am. Sec.) (Dec. 2) 1932.

8. Smatr, G. R. F. Post-Operative Vomiting, Brit J Anaesth 138, (July) 1934.

9. Bergman, W. Rehief of Post-Anaesthetic Vomitung through Pyridoxine, Canad. M. A. J. 56. 554, (May) 1947.

10. Kernis, L. and Stonsky, B. Failure of Pyndoxine in Post Anaesthetic Nausea and Vomiting, Anesthesiology 11: 212, 1950.

11. HiLl, F. W. Pyridoxne in the Treatment of Post-Anesthetic Nausea and Vomitng, Anesthesia 6 52, (Jan.) 1951.

12. Gay, L. N. and Carlinger, F. E. Science 109. 359, 1949

13. Carlinger, P. E., Radman, H M, and Gay, L. N. Treatment of Nausea and Vomiting of Pregnancy with Dramamine--Prelıminary Report, Science 110. 215, (Aug. 26) 1949.

14. Beeler, J W, Thussch, J H and Popp, W C Proc Staff Meetngs of tue Mayo Clinic: (Sept. 14) 1949

15 Campbell, E H The Effectiveness of Dramamine in Relieving the Vestibular Reactions Following the Labyrinthine Fenestration Operation, Laryngoscope 59: 1261, (Nov.) 1949

16 Peterson, M D. Anesthesiology 10. 767, 1949. (Correspondence).

17. Rudolph, C J, Park, D D, and Hamiton, C Treatment of Post-Anesthetic Nausea and Vomiting, J A.M.A. 144 1283, 1950. (Correspondence)

18 White, J M, Freedman, D, MCCaWLeY, E L, and Gray, W. D. Effect of Certain Dialkyl-Substituted Aminoalkyl-Bearnng Compounds on Ampmorphine-Induced Emesis, Federation Proc 9. 325 (March) 1950.

19. Friese, H. B, Bianchi, R G., and Hambourger, W E. P. Morphine-Induced Emesis in Dogs Treated with-Dimethylaminoethylbenzohydryl ether-8-Chlorotheophyllnnate (Dramamine), Federation Proc 9.,274 (March) 1950

20 WolfE, W. B The Use of "Dramamine" in the Prevention of Postoperative Nausea and Vomiting, Ann Surg, 136261 (1952).

21. Demade, $R$ and Dulong-De, Rosn 1y, C H Action du 3277 R P. (Phénergan) sur les vertiges et les vomissements tardufs dus à la streptomycine. La Presse Medicale, 56: 834 (1948) (Abstract).

22. HARPER, J. Prevention and treatment of travel sickness with promethazine chloro-

theophyllinate, Lancet $1: 1141$ ( 1951 )
23 GLASER, E M and Hervey, G R The prevention of seasickness with hyoscine, benadryl and phenergan, Lancet 2749 (1951)

24. Bethell, M F. Prevention of seasickness with hyoscine, benadryl and phenergan Eancet 2. 888 (1951).

25. Campbell, H. E The Statistcal Method Surgery 9825 (1941). 